\title{
Overcoming the Effect of the Socio-cultural Context: Impact of Teaching Evolution in Tunisia
}

\author{
Saïda Aroua $\cdot$ Maryline Coquide $\cdot$ Salem Abbes
}

Published online: 30 April 2009

(C) Springer Science + Business Media, LLC 2009

\begin{abstract}
In Tunisia, even though it is an Arab-Muslim country, the teaching of evolution is not forbidden. Nevertheless, the Muslim perspective makes learning about the biological basis of evolution difficult because of the harmony that exists between religion and science. Tunisian students have a mixed misconception: They explain the diversity of life as both a result of God's works and a result of evolutionary processes at the same time. This paper presents the external evaluation that assesses the impact of an approach to teaching evolution designed to help students distinguish between theological and biological (scientific) explanations. The comparative analysis between the outcomes of the pre- and post-teaching interviews shows some success in helping students to distinguish between the two types of arguments and to develop better understanding of evolution as scientific knowledge.
\end{abstract}

Keywords Evolution · Design of teaching · Epistemology · Scientific status $\cdot$ Socio-cultural context

\section{Introduction}

Even though Tunisia is an Arab-Muslim country, the teaching of evolution is not forbidden as in many Muslims countries or

\section{S. Aroua}

Faculté des Sciences de Tunis, Campus universitaire,

2092 Tunis, Tunisia

\author{
M. Coquide \\ UMR STEF ENS Cachan-INRP, UniverSud, \\ Paris, France
}

\author{
S. Aroua $\cdot$ S. Abbes \\ S. Aroua $(\bowtie)$ \\ Avenue du 20 mars 1956, \\ 7000 Bizerte, Tunisia \\ e-mail: saida.aroua@fss.rnu.tn
}

Institut Pasteur de Tunis, Tunis, Tunisia even some districts of the US (Alexander 2001). Nerveless, it appears problematic not only because of conceptual difficulties but also because of its interference with students' theological beliefs. Tunisian students' attitudes toward evolution vary from rejection to acceptance (Chabchoub 2001; Hrairi and Coquidé 2002). The rejection arguments are based on theological beliefs, whereas the acceptance arguments are scientific and theological at the same time (Aroua et al. 2001). The students seem to have a mixed misconception: They account for the diversity of life as both a result of God's works and a result of evolutionary processes; the whole explanation is considered the biological explanation by the theory of evolution. We can explain this fact by the effect of the Tunisian Muslim's socio-cultural context, which is concordist $^{1}$ (Schlegel 2004). This view is re-enforced by an ignorance of biological methodologies (Aroua et al. 2005) and biological teachings that equate biology with physics and do not consider the historical dimension of biology (Aroua et al. 2007). So Tunisian students do not understand that biological evolution is a science and, especially, a historical science. These facts affect the scientific status of teaching evolution.

Facing the weakness of the scientific status of evolution, we designed and assessed an approach to teaching evolution that helps student to develop epistemological reflections about the specifics of science (Smith 1994; Cobern 1994; Duven and Solomon 1994; Rudolph and Stewart 1998; Sandoval and Morrisson 2003) and, especially, the historical dimension and method of biological evolution.

In this paper, we briefly describe our teaching design and research method and report some results evaluating the impact of the teaching.

\footnotetext{
${ }^{1}$ Within a concordist context, there is harmony between religion and science. The knowledge is conceived in a conceptual and logical continuity between the scientific level and the theological one that expresses an ignorance of science methodologies (Schlegel, 2004).
} 


\section{Design Teaching}

The teaching approach was designed to address two difficulties:

- difficulty in recognizing that biological and religious reasoning are different,

- difficulty in understanding the scientific status of evolutionary science because of the limited understanding of scientific methods.

The teaching was designed to help students to:

- understand that evolution is an historic science,

- recognize evolution as scientific knowledge,

- separate evolution from creationist ideas.

The teaching had four main points:

- The students must become aware that there are at least two explanations for the diversity of living beings, not only one

- The scientific explanation requires empirical evidence obtained by investigative methods that are not experimental

- The teaching of evolution facts and mechanisms (according to the Tunisian educational content, 1998)

- The actual controversy related to the modeling of evolutionary mechanisms

The evolution lessons (eight hours) were released in normal class conditions with a subgroup class of a senior class scientific level that constituted of 15 students (1820 years) and a teacher trained in biology education, epistemology and history of sciences.

\section{Methodology}

To process the research data, we combined two methods. An internal instrument was used to assess the teaching, and an external one was used to assess the impact of the teaching. In this paper, we report the results of the external assessment that constituted pre- and post-teaching semistructured interviews, including open questions. The subgroup class was divided into three small groups of five students each. All the small group discussions were audiotaped and transcribed to process for content analysis. We used a macroscopic approach to identify the themes in discussion and a microscopic analysis (words and key expressions, location of grammatical connecters...) to mark indicators (Kerbrat-Orrechioni 1990; 2001) of epistemological evolution and change among the students.

\section{Results}

Pre-teaching Results

We marked five recurrent episodes in each of the preinterviews' content. The mains themes are: the diversity (episode 1); a "scientific" discourse (episode 2); a mixed discourse and a mixed misconception of the diversity of life (episode 3); emergence of questions (episode 4); a need to know more (episode 5).

One "Scientific" Argumentative Referential (Episode 2)

In response at the question "How do you explain the diversity of life?", the students explained that it is the result of the effect of mutations, chromosomal recombinations, meiosis, fertilization, adaptation, environment factors' influence, etc. They evoked, in particular, the mechanisms of teaching intraspecific variations ${ }^{2}$ (Fig. 1). They seem to have used arguments learned in the biology class. We designed the students' basis of argument as "scientific." We enclosed the adjective scientific in quotation marks because the arguments used by the students are, often, not scientifically correct. For example, we cannot explain diversity by such external factors as the direct effects of climate ${ }^{3}$.

\section{Two Mixed Argumentative Referentials (Episode3)}

Later, the discourse was reoriented following the question "Did you have another explanation for the diversity of life?" The students began to use a second referential different from the biology class ones (Fig. 2).

\section{A Mixed Conception of the Diversity of Life}

To characterize the students' conceptions, we located keywords and expressions and marked grammatical connectors.

Examples of extracts:

Extract from $\mathrm{Pg} / \mathrm{GIa}$

23. Imen: God created diversity among the living beings, and after that, there was another diversity that results in reproduction mutations, adaptation, etc....

Extract from $\mathrm{Pg} / \mathrm{GIIIa}$

32. Chaima: Yes God's creation constituted the firstdegree of diversity then sexual reproduction, mutations, effects of environmental factors etc. constitute the second-degree of diversity.

Then, if we consider that the grammatical connectors as "then" or "after" expressed a chronological succession, we

\footnotetext{
${ }^{2}$ Previous studied themes.

${ }^{3}$ The students have a Lamarckian misconception.
} 
Fig. 1 Characterization of the basis of argument before teaching evolution (episode 2)

\begin{tabular}{|c|c|c|c|}
\hline Theme & Keywords and expressions & $\begin{array}{l}\text { Explanation of the } \\
\text { diversity of life }\end{array}$ & \begin{tabular}{|l} 
Basis of \\
Argument
\end{tabular} \\
\hline $\begin{array}{l}\text { Explanation } \\
\text { for the } \\
\text { diversity of } \\
\text { life }\end{array}$ & $\begin{array}{l}\text { Individual ; Transformation; } \\
\text { chromosomal recombinations; } \\
\text { Mutations ; Meiosis ; Random; } \\
\text { Fertilization; Differencies } \\
\\
\text { Environmental factors ; new } \\
\text { species ; Adaptation ; } \\
\text { environmental ; live; climate }\end{array}$ & $\begin{array}{l}\text { Life's diversity is } \\
\text { explained by internal } \\
\text { factors: random mutations, } \\
\text { chromosomal } \\
\text { recombinations, meiosis, } \\
\text { Fertilization } \\
\text { and/or } \\
\text { by external factors: } \\
\text { climate, environmental } \\
\text { live, environmental } \\
\text { factors }\end{array}$ & $\begin{array}{l}\text { «Scientific » } \\
\text { referential }\end{array}$ \\
\hline
\end{tabular}

could understand that the students' explanation was a mixture of two different ideas: theological and scientific ideas. Indeed, according to the students, the diversity results from God's creation that constitutes a first level of diversity, then it is followed by a second level of diversity, thanks to sexual reproduction, mutations, effects of environmental factors, etc. In addition, they considered this mixed explanation as the biological explanation according to the theory of evolution (Fig. 3).

\section{Extract from $\mathrm{Pg} / \mathrm{GIIIa}$}

57. Rahma: The species were created, then they adapted to the change of environmental factors.

58. Nouha: Yes, they evolved; it is the theory of evolution.

59. Abir: Yes.

\section{Post-teaching Results}

We marked four recurrent episodes in each of the postinterviews content. The main themes are: scientific explanation of the live diversity (episode 1); two different explanations of the diversity of life (episode 2); two methods for scientific evidences: experiences and inquiry (episode 3); a need to know more (episode 4).

Next, we marked in each episode the indicators of epistemological change among the students, especially the ones that indicate that the students were able to separate the scientific and the theological knowledge.

\section{Scientific Explanation of Life's Diversity (Episode1)}

As we show in Fig. 4 and in the contrasting pre-test, the students used only one argument to explain the diversity of life.

But, at this stage of the discourse, we considered it too soon to conclude that there was a really epistemological change among the students. Then we completed this assessment with a location and an integration of other epistemological change indicators in the following discourses:

- evolution knowledge construction, characterization of the methodology validation in science evolution, discussion
Fig. 2 Characterization of the basis of evidence before teaching evolution (episode 3)

\begin{tabular}{|c|c|c|c|}
\hline Theme & Keywords and expressions & $\begin{array}{l}\text { Explanation of the } \\
\text { diversity of life }\end{array}$ & Basis of Argument \\
\hline $\begin{array}{l}\text { Explanation } \\
\text { for the } \\
\text { diversity of } \\
\text { life }\end{array}$ & $\begin{array}{l}\text { God ; origin of live, God } \\
\text { creation of one male and one } \\
\text { female of each specie; no } \\
\text { diversity ; diversity is created; } \\
\text { Adaptation ; Environmental } \\
\text { factors ; God orders all } \\
\text { environment factors; God had } \\
\text { created than the nature, ordered } \\
\text { by God, make the diversity ; } \\
\text { Creation ; } \\
\text { Diversity ; Mutation ; New } \\
\text { traits ; Environmental factors ; } \\
\text { Changes ; Living beings ; } \\
\text { Changes ; God creation than } \\
\text { other changes; God creation } \\
\text { make restricted diversity; God } \\
\text { creation constituted the first- } \\
\text { degree of diversity then sexual } \\
\text { reproduction, mutations } \\
\text { constitute the second stage; } \\
\text { theory of evolution. }\end{array}$ & $\begin{array}{l}\text { Life's diversity is } \\
\text { explained by God } \\
\text { creation, } \\
\text { and } \\
\text { nature actions } \\
\text { ordered by God } \\
\\
\text { and/or } \\
\text { life's diversity is } \\
\text { explained by internal } \\
\text { factors: random } \\
\text { mutations, meiosis, } \\
\text { fertilization } \\
\text { and/or } \\
\text { by external factors: } \\
\text { environmental } \\
\text { factors, adaptation = } \\
\text { evolutionary theory. }\end{array}$ & «Religious » argument \\
\hline
\end{tabular}


Fig. 3 Analysis of a misconception about the diversity of living beings

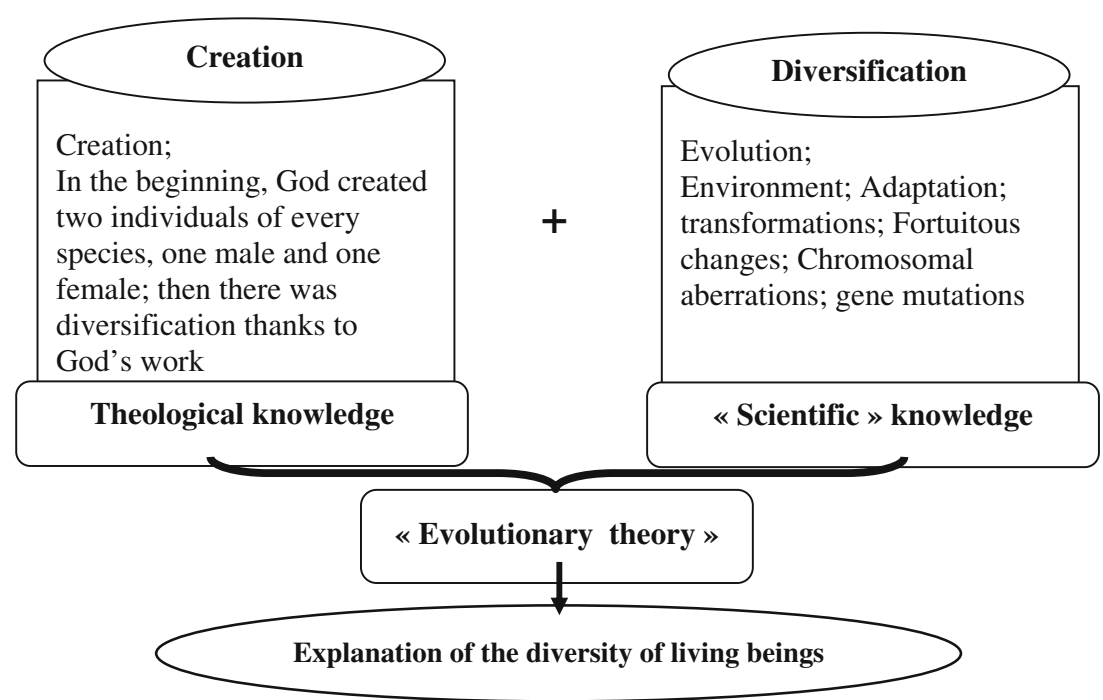

about proof in science, questioning (other questions, more precise questions);

- call misconceptions into question.

\section{Evolution Knowledge is Distinguished from Creationist Ideas}

The speech of some students shows that they make a separation between evolutionary ideas and creationist ones. They argue in reference to biological evolution knowledge learned during the teaching under consideration.

Dorsaf made the separation. Also, she did not hide her adherence to the evolutionist argumentations.

Extract from $\mathrm{Pg} / \mathrm{GIIb}$

44. Dorsaf: The diversity results from mutations, speciation and natural selection. These three mechanisms are together the reason for diversity and evolution. I think that these explanatory mechanisms are three very convincing arguments. Arguments that are, for me, more convincing than creation.
According Ines and Manel, it is necessary to separate the two explanations.

45. Ines: Yes, it's necessary to separate the two explanations because one says that species are descended from a common ancestor, the other says ...

46. Manel: That species are God's creation. It is necessary to separate to avoid falling wrong.

Distinction Between the Scientific and the Theological Basis of Argument

Sawsen justified the differences between the scientific and the theological basis of argument.

Extract from GIIIb

41. Sawsen: According to religion all things were created, as they are actually. They are like this because they were created like this. We cannot do anything. Whereas, if we have a scientific attitude, we will ask why living beings were like this? How they evolved? What proves that they evolved? That is, we will act like the scientist.
Fig. 4 Characterization of the basis of evidence on post-teaching evolution (episode 1)

\begin{tabular}{|l|l|l|}
\hline \multicolumn{1}{|c|}{ Theme } & \multicolumn{1}{|c|}{ Keywords and expressions } & Basis of Argument \\
\hline $\begin{array}{l}\text { Explanation } \\
\text { for life's } \\
\text { diversity }\end{array}$ & $\begin{array}{l}\text { Gathering of many process; Mutations; } \\
\text { Transformations; Generations; New species; Evolution } \\
\text { during many generations; DNA; genetic information; } \\
\text { protein synthesis; DNA replication; errors; Genes; } \\
\text { Chromosomes; Meiosis; Random; species; Differences } \\
\text { within the specie; Earth transformations; Observations; } \\
\text { Resemblance; present animals; Fossils; biological } \\
\text { evolution; common ancestor; Relationships between } \\
\text { species ; Natural selection; Speciation; Inter-sterility; } \\
\text { Fertilization; Inter-fertilization; anatomic evidences; } \\
\text { Comparisons; old animals; paleontological evidence; } \\
\text { embryological evidence; gradual evolutionary changes } \\
\end{array}$ & \\
\hline
\end{tabular}


Interrogation About Misconceptions of the Diversity of Life

Interrogation about their misconceptions of the diversity of life was possible when the students began to be able to propose personal opinions.

Some students, such as Asma and Manel, expressed it overtly.

Extract from $\mathrm{Pg} / \mathrm{GIIb}$

16. Asma: (...) Before this teaching, we could not differentiate the two explanations. Now, I think that we are able to separate the two ideas...

Extract from $\mathrm{Pg} / \mathrm{GIIb}$

35. Manel: I think that we have the same problem: the diversity question. It is the same problem, it has two solutions. The first, there is creation. God creates all living beings and changes them. The second is given by science, there is an evolution.

\section{Students' Interrogation Increasing}

Once the students understood there has been evolution among living beings, the question that remained was "how do scientists explain the origin of life?"

Extract from $\mathrm{Pg} / \mathrm{GIIb}$

70. Manel: Now my problem is the origin of the common ancestor: how do the scientists explain its origin?

\section{Conclusion}

Our research shows that using an epistemological approach, especially epistemological reflection, to address difficulties to understand the scientific status of evolution leads to:

- a manifest development of epistemological reflections among the students, assisted by the teacher's interventions

- a construction of knowledge about methods of validation in evolution

- a characterization of the scientific basis of evolution, and especially

- a separation between evolutionary and creationist ideas

These results would indicate an epistemological change among the students resulting from an understanding of the scientific status of evolution. Thus, we could form a hypothesis that the inclusion of epistemological reflection about the nature of science and the specificities of historical science when teaching about evolution can help students to understand the scientific status of evolution. This approach appears to help Tunisian students to distinguish between scientific knowledge about evolution and creationist ideas and would seem to be an essential step in preparing to teach evolution as a science in the Tunisian social context. In such socio-cultural context, contextualizing the teaching of evolution seems to be an essential step. Thus, for a complete and authentic education, the teaching of the theory of evolution must take place in a pedagogical, intellectual, and also a social context (Anderson 2007).

Acknowledgements We express our deepest thanks to Greg Eldredge who encouraged the publication of this work.

\section{References}

Alexander, D. (2001, trad. fr. 2004). Science et foi. Evolution du monde scientifique et des valeurs éthiques. Paris : Frisson-Roche.

Anderson RD. Teaching the theory of evolution in social, intellectual, and pedagogical context. Sci Educ. 2007;92(4):664-677.

Aroua, S., Coquidé, M., \& Abbes, S. (2001). Les rapports d'élèves tunisiens à l'évolution biologique et leurs référentiels d'argumentations, Skolé, Numéro hors série. 177-187.

Aroua S, Coquidé M, Abbes S. Faut-il former les enseignants à l'épistémologie de la biologie ?: Cas de l'évolution biologique. Revue de la Faculté des sciences de Bizerte. 2005;4:49-55.

Aroua S, Coquidé M, Abbes S. Fragilité du statut scientifique de l'enseignement tunisien de l'évolution au secondaire et à l'université : analyse des contenus enseignés. Revue de la Faculté des sciences de Bizerte. 2007;6:9-18.

Chabchoub A. Rapports aux savoirs scientifiques et culture d'origine. In: Charlot $\mathrm{B}$, editor. Les jeunes et le savoir. Perspectives internationales. Paris: Anthropos Education; 2001. p. 117-132.

Cobern WW. Point: belief, understanding, and the teaching of evolution. J Res Sci Teach. 1994;31(5):583-590.

Duven J, Solomon J. The great evolution trial: use of role-play in the classroom. J Res Sci Teach. 1994;31(6):575-582.

Hrairi S, Coquidé M. Attitudes d'élèves tunisiens par rapport à l'évolution biologique. Aster. 2002;35:149-164. Paris : INRP.

Kerbrat-Orrechioni C. Les interactions verbales, Tome I, Approche interactionnelle et structure des conversations. Paris: Armand Colin; 1990.

Kerbrat-Orrechioni C. Les actes de langage dans le discours : Théorie et fonctionnement. Paris: Nathan Université; 2001.

Ministère de l'éducation. (1998). Programmes Officiels de l'Enseignement Secondaire.Décret $n^{\circ} 98-1280$ du 15 Juin 1998. Annexe XII. Sciences naturelles, République Tunisienne, Ministère de l'Education, Direction des programmes.

Rudolph JL, Stewart J. Evolution and the nature of science: On the historical discord and its implications for education. J Res Sci Teach. 1998;35(10):1069-1089.

Sandoval WA, Morrisson K. High school students' ideas about theory change after a biological inquiry unit. J Res Sci Teach. 2003;40 (4):369-392.

Schlegel, J-L. (2004). Les dangers de l'harmonie à tout prix. La Recherche, Hors-série, 14, Dieu et les Sciences, 74-77.

Smith MU. Counterpoint: Belief, understanding, and the teaching of evolution. J Res Sci Teach. 1994;31(5):591-597. 